\title{
Western Feminism and Rescuing Non-Western Women
}

\author{
Manha Waheed ${ }^{1}$ and César Cabezas ${ }^{\sharp}$ \\ ${ }^{1}$ Markham District High School, Markham, ON, Canada \\ \#Advisor
}

\section{$\underline{\text { ABSTRACT }}$}

Western feminism has become one of the most widespread feminist ideologies in our world today and it continues to gain popularity among those in the West who attempt to aid women in foreign nations. This particular feminism is rooted in "saving" non-Western women by attempting to mold their lives so that they may feel "empowered," much like women in the West. What Western feminism fails to account for, however, is the lack of knowledge towards cultural contexts and the harm caused by Western feminists as they attempt to save these women who they deem oppressed due to their culture. The purpose of this paper is to analyze Western feminism from a variety of perspectives and find the flaws that prevent it from actually having a positive impact on women in the Global South. This essay includes references to prominent philosophic literature as well as present and historical examples of Western feminism that prove that the White Ignorance prevents these types of feminists from actually "rescuing" oppressed women. Through analyzing Western feminism from different lenses of White Ignorance, this paper provides an answer for how feminism can have a genuinely positive impact on non-Western women through the abolition of Structural White ignorance found in Western institutions and corporations.

\section{Introduction}

For centuries now, women across the globe have faced astronomically difficult challenges that have led to an overall decline in their mental, physical and emotional wellbeing. As the world progressed, Western societies quickly rose to the top of the global hierarchy and those Western nations thought of themselves as having the superior, fairest, and most correct way of life. It became a widespread conception that women in the West were much more "privileged" and far less "oppressed" than women in the Global South. Time and time again, Western society tried to swoop in and save the women they deemed as oppressed. To this day, this pattern continues. Although many times Western feminists aren't wrong about labelling the women they chose to save as "oppressed," they are very much wrong when it comes to the idea that these women are oppressed only because of their culture. Western feminists consider their culture to be superior, which often leads to the misconception that non-Western cultures are built to oppress women. In other words: to "save" a woman from oppression, you must completely cleanse her of her culture. Although this may sound extreme, it is one of the main drives behind Western feminism. But where does this misconception really come from? What are these ideas truly rooted in? How else do we battle the oppression of Non-Western women? Those are the questions that I will be addressing throughout this essay.

To clarify, I refer to Western feminism as a strain of feminism that is very apparent in the West which incorporates ideas of ethnocentrism and universalism. Ethnocentrism refers to analyzing other cultures with preconceived notions that arise from one's own culture. In this case, Western feminists judge other cultural practices based on what Western culture deems to be oppressive or harmful. Universalism, in opposition to relativism, suggests that there should be a global set of laws that apply to every situation. Universalism in this context can be seen as Westerners applying every rule in Western culture, to every foreign culture as well, despite the differences in context. In simple terms, I see Western feminism as a view that elevates Western culture while criticizing non-Western cultures. It is 
also important to note that I use the terms "Missionary feminism" and "Western feminism" interchangeably throughout the essay.

In this essay I will argue that we will never truly be able to solve universal women's oppression until we combat the Structural White Ignorance rooted in governments, giant corporations, and other massive institutions that shape our everyday lives. In order to build my argument, I will start by going through three examples of Western feminism, all of which are from different periods of time, in order to show a crucial pattern of White Ignorance that arises when one examines cases of missionary feminism. I will then move on to analyzing this White Ignorance from three different lenses: the Individualist view (or the Wilful ignorance view), the Cognitivist view and the Structuralist view. I will go into why I believe that the Structuralist view is the most fitting view on white ignorance when it comes to western feminism. Lastly, I will show that the Structuralist view best explains how white ignorance causes many missionary femenist attempts to "rescue women from oppression" to ultimately fail. I will go deeper into why women across the globe, whether they are foreign women living in Western countries or a Non-Western women living in their native countries, will never fully be saved from the clutches of sexist oppression until we solve the issues that come about by white ignorance being highly present in powerful institutions.

\section{Methods}

In order to answer the questions, I had posed, I conducted secondary analysis on prominent philosophical literature centered around Feminism and White Ignorance. My main methods of qualitative analysis included Discourse Analysis and Thematic Analysis. To better understand the similarities and differences between Western and other feminist ideologies, I began by analyzing Serene Khader's “Decolonizing Universalism: A Transnational Feminist Ethic," a book that discussed common areas of discourse within Feminist Philosophy. Once I had a better understanding of Western feminist views, I analyzed other academic papers discussing the difference between Western feminism and more relativist feminist views in order to find patterns that would aid in answering my questions. Two such papers which I reference in this essay include "Saving Amina': Global Justice for Women and Intercultural Dialogue" by Alison M. Jaggar and "Do Muslim Women Really Need Saving? Anthropological Reflections on Cultural Relativism and Its Others" by Lila Abu-Lughod.

One of the main patterns I noticed by conducting thematic analysis was the prominent role White Ignorance played in Western Feminist Philosophy. I then began to read and analyze essays pertaining to different types of White Ignorance and its presence in today's society. "Managing Ignorance" by Elizabeth V. Spelman and "What is White Ignorance?" by Annette Martín are two important papers mentioned within this essay. It Is important to note that although I support my claims with a variety of philosophical literature, I also used information from news articles and encyclopedia websites, such as "Britannica" and "The Canadian Encyclopedia," to provide further insight on issues within this paper that help build my argument. As I researched present and historical examples of Missionary feminism, the pattern of White Ignorance continued to be prevalent and I was able to easily find concrete examples that support my thesis. I ended up analyzing a wide variety of sources in order to use real-world examples and elements from philosophical literature to create a basis for my theory.

\section{Westem Feminism and Examples}

To illustrate the patterns of Missionary feminism, I will be breaking down three examples of people from the West attempting to "save" women who they deemed oppressed. The examples are as follows: the assimilation of First Nations Canadians into European culture, the relationship between the US and Afghanistan, and lastly, France and its transition into becoming a secular state. By the end of this section, you will find that there is a common pattern of White ignorance in every case of Western Feminism involving the idea of "saving women." 


\section{The Assimilation of First Nations Canadians:}

\section{Brief Overview of The Indian Act and its Effects on Indigenous Canada:}

After the Confederation of Canada was established in 1867, there was a plan to assimilate Indigenous Canadians into "White Canadian" culture. This plan was driven heavily by the "Indian Act" which was first introduced in 1876, nine years after Canada gained independence. This act was the primary law that the government utilized to control the Canadian Indigenous population as it combined almost all laws pertaining to First Nations into one document. Although this act is still in place, it has been amended many times over the past century and a half in order to remove major discriminatory aspects which were now seen to be clearly offensive and hurtful towards the Indigenous community in Canada (Indian Act, 2006).

When it was first created, the Indian act defined an "Indian" to be any male person of Indian descent who belonged to a particular band, any child of such Indian person and any woman who was lawfully married to an Indian man (Indian Act, 2006). If you were considered to be an Indian, you were not legally qualified to make decisions for yourself. The Canadian Government was legally allowed to make decisions for anyone considered an Indian person without the consent of that person (The Indian Act, 2009). The Indian act is also famous for reinforcing reserves, which were areas of territory that the Native Canadians were forced to live in. These areas were often unsafe, isolated, and overall an unpleasant place to live (McCue, 2011). It became very apparent, as Canada continued to grow in population, that White Canadians required new land for farming and living. To solve this issue, other treaties were created in effort to "buy" land from Indigenous Canadians. The infamous Toronto purchase, which took place in 1787 (Boileau, 2021), as well as other Similar treaties like this were made to make it seem as though the Canadian government was fairly taking this land, when in reality, it was merely being stolen. Lastly, the Aboriginals were not considered Canadian Citizens if they held the "Indian" status, and only Canadian Citizens were allowed to vote (The Indian Act, 2009).

As time went on, more and more rules were put in place against the Indigenous. Cultural rituals and ceremonies were banned. Two of the most well-known being the "Sun Dance," a sacred ritual which had been passed down from generation to generation for centuries, and the "Potlatch," a traditional gathering where the Natives would cook amongst themselves and all contribute to a party filled with music, dancing and enjoyment (Indian Act, 2006). In 1884, the Potlatch was banned and from 1895 onwards, Natives were forbidden from wearing their traditional clothes or participating in local dances (Indian Act, 2006). Post-confederate Canada also brought about the creation of residential schools (Indian Act, 2006). Residential schools were boarding schools, often located very far away from reserves. It is a common saying that residential schools were built in an effort to "kill the Indian in the child." The story of residential schools is truly heart breaking and will be discussed in depth later. For now, however, we need to understand that the main purpose of residential schools was to remove Indigenous children from their cultural environment and force them to assimilate into White Canadian way of life. These children were suddenly taken away from their homes and forced to forget everything they had ever known.

With such rules implemented, clearly working against anyone who was considered to be Indian, it would seem as though the government was making it an extremely unpleasant experience to hold onto your cultural identity. There were however a few ways one could escape these rules. The Indian Act declared that one would lose their "Indian" status if they either earned a university degree or travelled abroad and did not return to Canada after over five years (Adler, 2014). This meant having to choose between things like serving your nation in the military for long periods of time and gaining an appropriate education or not losing your identity and culture completely. It is blatantly clear that 


\section{First Nations Canadians were not treated like humans:}

\section{How did this Affect Indigenous Women?}

How did this attempt to abolish Indigenous culture hurt women? There are a few key areas to focus on in order to answer this question: the status of a woman after marriage, the loss of power of Indigenous women in their tribes and homes, and lastly, the residential schools.

I mentioned before that it was possible for an Indigenous person to lose their "Indian" status. Although I only listed two ways of how this could happen, there was actually another one that I did not mention because it only pertains to women. Recall the definition of a woman who is considered Indian: any woman who is lawfully married to an Indian man. Now, if a woman were to marry a White man however, she would lose her Indian status and be treated like a Canadian citizen (McNab, 2006), or what was thought at the time to be a "liberated" woman, free from the "savage Indian lifestyle." One may think that this law positively affected women, what this rule really did, however, was degrade the status of a First Nations woman even more. She was nothing by herself and could only be given a label based on which man she chose to marry. In an even more depressing sense, if a woman wanted to marry a white man, she would have to think twice because marrying him meant losing her entire culture, identity and everything she had ever known her whole life. This decision of choosing between marriage and culture, as well the cultural identity of a woman being decided by marriage rather than upbringing, were blatantly oppressive.

Prior to British rule and the Colonization of Canada, Indigenous women, especially elders, were held at a very high status. Women in general held a lot of domestic power. Although men would often hunt, women were seen to be more mentally strong due to their ability to bear children and their roles within bands (Marginalization of Aboriginal women, 2009). Elders, especially female elders, were believed to be the wisest of people in bands and that's why they were chosen as chiefs or rulers. There was a very high amount of respect given to any elderly women; in fact, they were probably known as the most respected people in the tribe. Life of Indigenous women prior to White Canadian society was anything but oppressive. Once the Canadian government created the Indian act, however, this equality of power was stripped from Indigenous women. Rules were put in place to control the governments of each band (The Indian Act, 2009). Women were taken out of the band governments and were no longer allowed to be held to such a status. Furthermore, the Indigenous were encouraged to live a more "European Canadian" lifestyle by farming and reducing women to only their household abilities (Marginalization of Aboriginal women, 2009). Thus, Native women not only lost their tribal status, but their household status as well.

The Mohawk Institute was the first residential school to be opened in 1831 (Residential Schools in Canada, 2012). Located in Brantford, Canada, It was the first of many boarding schools where Indigenous children, as young as three or four, were taken to, after saying goodbye to their families. These children were exposed to the "European environment" (Residential Schools in Canada, 2012). Their long, braided hair was considered messy, so it was cut short. Their clothes and belongings were considered filthy, so they were taken away and replaced with clean, pure European clothes. Their language was considered savage and impure, so they were forced to learn and speak only English. If they refused to comply with the orders given to them by school staff, they would be punished (Residential Schools in Canada, 2012). Children were also severely abused, mentally, physically and sexually (Residential Schools in Canada, 2012).

The outcome of residential schools was traumatic and gruesome, to say the least. Although residential schools were not only for young Indigenous girls, they still played an important role in the harming of Indigenous women and girls in Canada. The experience of the schools themselves were unarguably torturous and not only left these girls traumatized, but the boys as well. Women who were traumatized were left with an array of mental and physical health conditions that stayed with them for the rest of their lives (McNab, 2006). Men, who also dealt with similar trauma, resorted to drugs, abuse and other ( $\mathrm{McNab}, 2006)$. This created a chain reaction of generation after generation of Indigenous families living in abusive and toxic households (Menzies, 2020).

The effects of residential schools and assimilation laws can still be seen in the Canadian, Indigenous community today. The "generation to generation" issue I brought up is still very much existent. Families who were affected by 
residential schools were left so traumatized that they developed a variety of mental health issues (Menzies, 2020). This mental illness and trauma followed them throughout the rest of their lives and led to a toxic household environment. Their children had to endure all that negativity, which just led to even more trauma for them as well (Menzies, 2020). This chain of negativity continued to be passed down and eventually led to almost every family living in Canadian reserves to suffer from some sort of mental illness or trauma. Clearly residential schools completely stripped Indigenous women of any status, dignity or identity that they had left.

Overall, the European Canadians believed that the Indigenous culture was "savage" and "unholy" while women, on the other hand, were "pure" and "agile" beings. In order to "save" these Indigenous women from that Savage culture, they put laws and regulations in place to allow women to escape the lifestyle. Although European Canadians would argue that the laws they set for Indigenous women (e.g., allowing her to marry a white man in order to escape the savagery of indigenous culture or "teaching her" about White culture...) were beneficial, we know that history shows that was simply not the case. Instead of being "saved" from their supposedly "savage" culture, Indigenous women actually became severely oppressed under White-Canadian rule. Women in Indigenous Canadian culture, prior to European arrival, were treated well, put to a high status, seen as strong and authoritative figures. It was the Europeans who brought with them these negative aspects of womanhood (e.g., being weak, not being able to participate in government, etc...). After the attempt to save women from the wrongfully accused "savage" Indigenous culture, Indigenous women were forced into a life of mental, physical and emotional trauma. Evidently, it was these misconceptions that White Canadians had of women being weak and Indigenous culture being savage and oppressing, rather than the First Nations' culture itself, that led to the oppression of Native Canadian women.

\section{The Relationship Between the US and Afghanistan:}

\section{Brief Overview of The Taliban, al-Qaeda and US War in Afghanistan}

After the withdrawal of Soviet troops from Afghanistan in 1889, the country's communist regime collapsed and there was a severe lack of order. This gave rise to a new religious, political group: the Taliban (Taliban, 2001). The Taliban rose to power in 1994 in the province of Kandahar, located in southern Afghanistan (Taliban, 2001). The group was able to quickly seize power from local warlords and control the entire south of Afghanistan. In a mere two years, the Taliban was able to gain support from ethnic groups and conservative Muslims, leading to the group taking over control of Kabul, the capital, in 1996 (Taliban, 2001). By 2001, the Taliban had control over most of Afghanistan, only leaving behind a small section of northern Afghanistan (Taliban, 2001). It was the Rise of the Taliban and its control over the Afghan Government that led to the rise of the infamous Islamic military organization, Al-Qaeda (Taliban, 2001).

Al-Qaeda was originally a logistical network intended to support Muslims during the fight against the Soviet Union (Al-Qaeda, 2003). Members of the organization were from a variety of Islamic nations. After the withdrawal of the Soviet troops, the group disbanded but continued to oppose liberal, foreign and, what they thought of as "corrupt," Islamic ideology in Islamic nations. After the Taliban started gaining more power in 1996, Al-Qaeda re-established themselves in Afghanistan, with the support of the new political group, under the leadership of Osama in Laden (Al-Qaeda, 2003). As time went on, Al-Qaeda merged with other Islamist groups such as the Jihad, an organization with similar schools of thought, based in Egypt (Al-Qaeda, 2003). Al-Qaeda took part in numerous terrorist attacks, including the infamous September 11 attacks on the Twin Towers and the Pentagon (Al-Qaeda, 2003). Although the group had continuously declared holy war against the US and attempted to create conflict many times previously, the September 11 tag acted as a breaking point for the United States. Soon after that attack, the US responded by attacking al-Qaeda forces in Afghanistan (Al-Qaeda, 2003). This was the start of a long period of war between the US and the Taliban, which had almost complete control of Afghanistan's central government at the time.

Osama bin Laden went into hiding for the majority of the decade and was killed ten years later by US military forces once he was found in Abbottabad, Pakistan (Al-Qaeda, 2003). Although the United States, and former President Barack Obama, considered this a significant win, the war was far from over. al-Qaeda was quick to appoint a new 
leader: Ayman al-Zawahiri, bin Laden's long serving deputy (Al-Qaeda, 2003). After almost two decades of ongoing conflict, the United States and Afghanistan finally started negotiations in 2018, with the help of the only countries known to be on good terms with both major parties involved: The United Arab Emirates, Pakistan and Saudi Arabia (Taliban, 2001). Conflict and attacks, although significantly less, did continue to occur a few times during the period of negotiation between 2018 and 2020. The United states slowly began bringing troops back in March of 2020 (Taliban, 2001). Negotiations between the Taliban and Afghanistan's central government began in September of 2020 (Taliban, 2001).

\section{How Did This Affect Afghan Women?}

When the U.S first declared war in Afghanistan, the first lady at the time Laura Bush gave a speech in which she stated the United States would rescue Afghan women from the oppressive environment they were in (Abu-Lughod, 2002). In her book, "Do Muslim Women Really Need Saving?" Lila Abu-Lughod (2002) explores the United Sates relationship with Afghanistan and how it directly impacted women. In a portion of this essay, Abu-Lughod (2002) analyses the "white saviour complex" that is present in Western Feminism. In this section, she provides a quote from, the at the time first lady, Laura Bush: "Because of our recent military gains in much of Afghanistan, women are no longer imprisoned in their homes. They can listen to music and teach their daughters without fear of punishment..." This quote speaks volumes of how the U.S government, acting from a place of Western feminism, views itself and the culture it is attempting to rescue these women from. Throughout this next section, I will clearly illustrate that although the U.S sees themselves as only a positive entity in this fight against women's oppression in Afghanistan, the nation actually had many negative effects on Afghan women.

It is true that the Taliban itself had a significant effect on the lives of women in Afghanistan due to their radical Islamic beliefs. Most notably, women were forced to wear niqab, in other words veil themselves, as well as act in accordance with Islamic law. There were severely strict punishments in place for breaking any rules that the Taliban reinforced. It is important to take into account three main points when analysing this situation:

1. The Taliban itself, although claiming to follow Islamic beliefs, broke many basic rules put in place to protect women in Islam.

2. The United States actually played a large role in allowing the Taliban to gain its power.

3. Many objectively oppressive cultural practices in Afghanistan were actually put in place due to the United States.

Firstly, it is very important to understand that many of the Taliban's beliefs are actually not rooted in proper Islamic law. This is an issue that occurs not only when large groups attempt to be radically religious or conservative, but in individuals as well. In an attempt to reinforce certain parts of any religion, many radicalists tend to overlook other parts a religion that may be completely against their own perception of that religion or their understanding in how a religion should be enforced. In this case, the Taliban did just that. In an attempt to force women to adhere to Islamic law, the group actually ignored many important rules that protect women from oppression in Islam. One major example is the forcing of women to veil or wear the burqa (Maizland, 2021). There is a notably important rule in Islam that states although covering of the hair is mandatory, the covering of the face is actually not seen as mandatory (Fatawa - Niqab, 2004). In addition to that, the act of forcing the veil upon a woman, by any male figure (father, brother, husband, etc..), is not allowed (Fatawa - A Father Forcing His Daughter to Wear the Hijab, n.d.). There is a clear distinction between a woman choosing to follow her religion and being forced to do so in Islam. In this case, the culture or religion itself cannot be considered the reason for women's oppression, the actual cause stems from the actions of a group, not the religion itself. Western feminism, however, sees Islam as the clear root of women's oppression in Afghanistan. This misconception is there due to the clear lack of knowledge on Islam itself as a religion.

Secondly, it is crucial to understand the role that the United States originally played in aiding the Taliban in its rise to power. To gain a better understanding of this, I will be turning to Alison Jagger's essay titled "Saving Amina: Global Justice for Women and Intercultural Dialogue." In a section of this essay, Jagger (2005) goes over how Western culture and Western nations don't merely pay a passive role in the reactions of those who make decisions to oppress 
women. "The Taliban government of Afghanistan, which also practiced gender apartheid, was installed after the United States provided extensive training and aid to various mujahedeen forces opposing the, then-communist but secular, government" (Jaggar, 2005). From this, we can infer that the US was not just a passive party in the Taliban's rise to power, but in fact, acted as a catalyst. The U.S clearly played some role in allowing the Taliban to gain power. Even if it was indirect, it is false to claim that the United States played no part in helping build up the Taliban.

Lastly, many of the cultural practices that are labelled as oppressive were put in place due to the US itself. There are two things we can turn to in order to further explain this point: the war itself and the United States role in Afghanistan after the defeat of the Taliban. First, we must look at the effects of the war on Afghan women. One main oppressive practice that Western feminists refer to when talking about Afghan women is the culture of forced marriages at a young age (Jaggar, 2005). It wasn't until the U.S started war in Afghanistan that the environment of the country became much more dangerous, both socially and physically, especially for women. Out of desperation, families were forced to marry off their daughters at a younger age in order to protect them. To put it simply, when the United States actually started the war, Afghanistan became a much more hostile place and in order for young women to survive, they had no choice to be married. Another thing to note is that once again, like the forced veiling example, forced marriages are strictly prohibited in Islam (Muslim Women Network, 2011), meaning women were forced into participating in a practice that was, once again, Islamically unlawful. The second thing to look at is the state of women, post war. Although you would assume that women are living in much better conditions, that is simply not the case. Jagger (2005) also alludes to this in her essay: "Following its overthrow of the Taliban, the United States has installed a weak government in Afghanistan under which women's lives in many ways are just as precarious as they were under the Taliban." After the U.S overthrew the Taliban, they accomplished their goal of "saving the oppressed Afghan women," or so it seems. The current environment in Afghanistan is arguably worse that previously. With a weak central government, a built-in fear for women and girls and a society stuck with oppressing social practices from the war, the women are anything but saved.

Although it can be argued that the United States' original intentions were not harmful, it cannot be denied that they are hypocritical for acting as saviours when they in fact played a large role in harming Afghan women. The nation played a role in not only catalysing the Taliban's rise to power, which led to the political group oppressing women themselves, but also having a direct hand in forcing Afghan women to take part in oppressive practices by starting the war. The war in Afghanistan was supposed to be an attempt to save women from oppressive Islamic practices, when in fact, it just fuelled the oppression of Afghan women even more. Lastly, I mentioned a few times that many of the oppressive practices in this context were actually against Islamic law. When Western feminists say they are trying to save these women from Islamic traditions, not knowing the religion actually prohibits such behaviour and has rules put in place to protect women from any related oppression, it shows the evident lack of knowledge in many Western feminists.

\section{France and Religious Dressing:}

\section{Brief Overview of The Laws and Regulations}

On September 14th, 2010, the French government passed a law banning Muslim women from wearing religious veils in public places (French Senate Approves Burqa Ban, 2010). This ban included any face covering head gear, masks and niqabs as well as the burqa, a traditional Islamic dress that covers a woman from head to toe. In April 2011, France became the first European country to impose a ban on full-face veils in public areas (Veiled Women Arrested at Paris Protest, 2011). To this day, breaking these laws will result in a fine of up to $€ 150$ and/or participation in citizenship education (French Senate Approves Burqa Ban, 2010). The main purpose of these new regulations was to erase Islamic symbols from the public eye. France wanted to ensure that its public areas, such as schools, offices, malls and tourist attractions were stripped of any Muslim women displaying "radical Islamic beliefs." The anti-veiling argument has a few main points, and the French government did not hesitate to include some of those points in their explanation for this new law. 
1. The way Islam tells women to dress is oppressive.

2. It is the responsibility of the French Government to protect these women within the "public sphere"

3. Muslim girls should not have to be reminded of such oppressive rules when they are in public areas.

Point (1) is a very common argument used by many who oppose Islamic dressing. The argument basically goes as follows: Muslim women are "forced" to cover from head to toe and because of this they have no choice in what they wear or how they express themselves. The main issue with this argument is that it is not even Islamically correct. No man, whether that be a brother, father, son or any other male figure in a woman's life, is allowed to dictate what a woman wears. Forcing a woman to do anything, including wearing hijab or a niqab, is actually considered a sin in Islam (Fatawa - A Father Forcing His Daughter to Wear the Hijab, n.d.). Therefore, this argument is false. Let us now look at the women in Islam who chose to dress modestly and cover themselves. Muslim women who actually chose to cover themselves based on Islamic standards have consistently stated that they feel not only safer, but also empowered. Clearly, Islamic dressing does the opposite of oppressing women.

Point (2) is very simple. As a government, France believes that it is their responsibility to protect French citizens in the "public sphere." In other words, the French government must make sure that public spaces are safe and comfortable places for all citizens. As we know from point (1), Islamic dressing is seen as oppressive and harmful towards French women, and therefore, it must be removed from the public sphere in order to maintain a safe and comfortable environment. This leads me to point (3). To thoroughly explain point (3), I will be referring to Serene Khader's "Decolonizing Universalism: A Transnational Feminist Ethic." In the third chapter of her book, Khader (2018) states: "French philosopher and public intellectual Elisabeth Badinter advocates banning headscarves in public schools in strikingly similar terms...she writes: To tolerate the Islamic veil is not to accept a free being (in the form of a young girl); it is to open the door to those who decided, once and for all, to try to bend her to their wills. Instead of offering her a space of freedom, you send her the message that there is no difference between the school and her father's house." As you can see from that small excerpt, this entire argument basically states that because hijab, niqab and burqa symbolize oppression, a young girl should not be exposed to those oppressive symbols outside her home.

France is claiming that these girls are subject to cultural and religious oppression in their homes so the nation must make public spaces, like schools for example, a place of "freedom." The only way to make these girls feel safe in the public sphere is by removing any Islamic symbols that may remind them of their oppressive household environments. We already know that this argument is not valid because we have established that forcing of the veil is already against Islamic law. The quotation from Khader's book also gives us insight into the extent of France's plan to eliminate not only face coverings or modest wear, such as the burqa, but the hijab itself as well. The country however, felt the need to not make such a rash decision as they started off with the ban of facial veils and will likely move on to banning head coverings as well. In this case, it can be said that France wants to "save" Muslim women from the "oppressive" Islamic dressing. However, we know that Islam itself does not actually oppress women through dressing. Therefore, France's lack of knowledge is leading it to make decisions that negatively harm women, rather than save them.

\section{How Did This Affect Muslim Women in France?}

Needless to say, these new regulations were not taken well, by both the French Muslim community and Muslims across the world. It is evident that France's lack of judgement of Islamic dressing caused a huge uproar, the country being labelled as Islamophobic due to its past history regarding Islamic matters as well. This poor judgement once again stems from the lack of knowledge the French government has on the religion of Islam. There is an important point that is often brought up in the debate of Islam dressing: you cannot make decisions for a woman who chooses to wear clothes that abide by Islamic law until you yourself have been in her shoes (Khader, 2018). I believe that this point is very important to take into consideration, and a point which the French government clearly ignored when passing their laws. If you do not know first-hand how the majority of women feel when they wear the hijab, burqa or any other form of veil, then you should not have a say in what those women chose to do with their lives. I believe this 
argument is very much comparable to one that arises in abortion debates: men should not have a say in what women do with their bodies simply because they have no basis for making such decisions. It is clear that a Western feminist would likely agree with this argument against abortion. Then why is it that they would disagree with the argument for Islamic dressing? Clearly it is because of the blatant Islamophobia and ethnocentrism present in France and its government.

I touched on France being labelled as Islamophobic before and this continues to happen as time goes on. Recently, amidst the COVID19 pandemic, France, along with many other nations, made masks mandatory in public areas. This, of course, was a very much needed precaution in order to control the spread of the virus. When France made this law however, they went ahead and clarified that the veiling laws were still very much in place. "France's Interior Minister confirmed to The Washington Post that the burqa and niqab bans remain, and women who wear those coverings in public will be "punished with the fine provided for second-class infractions." (Jason, 2020). The rest of the world saw this as blatant Islamophobia. Even Human Rights activists had a say in these French laws over the past few years. More recently, in regard to COVID19, Human Rights Watch executive director Kenneth Roth Tweeted. "Can Islamophobia be any more transparent? The French government mandates masks but still bans the burqa" (Jason, 2020). In 2018, The United Nations Human Rights Committee stated that France's ban violated women's freedom of religion and "could have the effect of confining them to their homes, impeding their access to public services and marginalizing them." (Jason, 2020). It seems as though the majority of the globe disagrees with the integrity of France when it comes to this matter.

The last point I want to touch on is the way this law is being enforced by France and local police officers. In an article published for The Telegraph, "Dress code advice for Muslim travellers visiting France," Hazel Plush (2016) points out a few unsettling details about this law. For context, the "Burkini" is a modern take on a bathing suit that is shaped like a burqa, the burkini allows for Muslim women to enjoy their time at the beach, in swimming pools and any other areas where bathing suits are required. In this article, Plush (2016) warns Muslim women travelling to France to abide by the dress codes or else they will be fined and "punished." She also states that "photographs emerged of women being fined and forced by police to disrobe in public," while providing a photograph of such an instance occurring. This is shocking to say the least. Women being forced by police officers to disrobe in public is humiliating and a blatantly inconsiderate way to enforce these laws. The French government has no regard for how Muslim women feel. This is evident when you take into account the hypocrisy when it comes to this case. France claims that these laws must be put in place in order to benefit the Muslim women who want to escape from their oppressive households. Yet, it is clear that the people in charge of enforcing these laws are doing it in such a way that Muslim women continue to be publicly oppressed. Clearly the French government's true intentions are anything but pure.

\section{Explaining White Ignorance}

Now that I have examined a few examples of missionary feminism, I will be delving deeper into these patterns of White ignorance by attempting to find the root of this problem. For this next section, I will break down three different views on white ignorance: The Individualist (Wilful Ignorance) view, The Cognitivist view and The Structuralist view. The structure of this section is heavily inspired by Annette Martin's (2020) Essay titled "What is White Ignorance." I will define each view, illustrate it with the example of the Indigenous Canadians and lastly weigh the costs and benefits of that view. At the end of this section, I will provide a thorough overview as to why the Structuralist view is so important when understanding how we can combat the main issues in Western feminism.

\section{The Individualist (Wilful Ignorance) View:}

\section{Definition}

The Individualist, or Wilful Ignorance view, is cantered around the idea that "White people" stay ignorant for purely psychological benefit: maintaining a clear conscience and a pure image of one's nation, culture or race (Martín, 2020). 
Like the name implies, an individual chooses to wilfully ignore any matters pertaining to race simply because they do not want to believe that their ancestors may have played a role in harming others through racial discrimination or because they don't want to feel guilty for continuing to reap the benefits of white privilege. This type of ignorance may appear in the form of an individual refusing to believe evidence of racial discrimination, ignoring major events that led to the oppression of people of colour and refusing to acknowledge relevant issues in relation to race (Martín, 2020). For example, individual A refuses to acknowledge that they are more likely to get a promotion than their black colleague, who has identical qualifications, simply because they are white. Knowing and accepting the truth would make it difficult for this wilfully ignorant individual to continue benefiting from their racial privilege and would also taint the perfect image of their country, a just nation built on equality, that they have believed their entire life.

To more thoroughly illustrate this concept, I will be referring to Elizabeth Spelman's (2007) view on white ignorance. Let's say $W$ represents a "white individual" and $g$ represents the "grievances of black America." We can say that:

1. W does not believe $\mathrm{g}$ is true and does not want to believe $\mathrm{g}$ is true.

2. W does not believe $\mathrm{g}$ is false but wants to believe $\mathrm{g}$ is false.

Because $\mathrm{W}$ does not want to believe $\mathrm{g}$ is true (1), it is suggested that that deep down, W worries that $\mathrm{g}$ may be in fact true. W also worries that if $g$ is true, their perception of themselves and their country will be tainted. Although W does not believe $\mathrm{g}$ is false, because they do not want to believe it's false, they also don't believe that $\mathrm{g}$ is false (2). If $\mathrm{W}$ truly believed that $\mathrm{g}$ was false, they would have no worries about $\mathrm{g}$ being true in the first place. In other words, W does not believe $\mathrm{g}$ is false, however, $\mathrm{W}$ wants to believe $\mathrm{g}$ is false in order to maintain a clear conscience.

To summarize, a white individual does not believe that racial discrimination, white privilege and the struggles that come with being a person of colour exist, simply because they do not want to believe they exist. At the same time, however, this individual does not believe that these things don't exist, because if that were the case, they wouldn't be trying to convince themselves of their existence in the first place. This creates a sort of grey area where the individual must continue to ignore any matters pertaining to race in order to maintain that clear conscience and not taint their image of the west. There is an evident contradiction because one cannot simply agree and disagree with a matter. In this case, however, the white individual must be stuck in this grey area because if they dive deeper and actually look into the matter, they will be forced to accept it, thus hurting their conscience.

\section{How Does This Fit into the Assimilation of Indigenous Canadians?}

We can use this view to explain a key aspect of the Indigenous Canadians' case. Many modern-day White Canadians may choose to argue that the assimilation of Indigenous Canadians was not harmful, was not as intense as it is deemed to be, or may have not even occurred, simply for their own psychological benefit. A White Canadian will choose to avoid factual evidence of:

1. The severity of this historical event.

2. The impact this event had, and continues to have, on First Nations Canadians

3. The benefits that they and their ancestors have gained from the occurrence of this event.

These first two points pertain more to a White Canadian's view of their nation. Coming into contact with evidence that disproves this individual's view on (1) and (2) will force them to stop ignoring the fact that they've been trying to convince themselves that this issue was only as serious as they wanted it to be. This will lead to the individual tainting the ideal image they created in their mind of Canada as a nation and their White Canadian ancestors. The third point has more to do with the individual's perception of themselves. If a white Canadian chooses to ignore all the benefits that they gained from the assimilation of First Nations Canadians (land, goods, more opportunities, etc...) they will not have to face the guilt of gaining benefits from an event that ultimately hurt millions of others. This individual will not have to live up to the fact that they continue to live a peaceful and far less gruesome life than the average Indigenous Canadian who is still very much affected by the events of the past. 


\section{Pros and Cons of this View:}

Although the Wilful ignorance view helps us explain one key aspect of the Indigenous Canadians example, there are still a few key components of the Missionary feminist's need to "save women" that do not fit into this perspective of white ignorance. We used this view to explain why many Western feminists, or in this case white Canadians, may choose to stay ignorant of certain facts pertaining to race and different cultures in order to maintain a clear conscience and reinforce this idea of "the west is best." The Individualistic view, however, does not give us an answer to many other questions. Why do so many westerners feel the need to "save women" from their culture? Why is it that Western feminists feel like they are genuinely helping women when they try to "save" them? Why is there a pattern of dominant Western feminist beliefs that do nothing but negatively affect non-Western women? The Individualist view is therefore not broad enough as it only pertains to strictly white individuals and assumes that the motive behind this ignorance is purely for self-beneficial reasons. The idea of saving women however alludes to the fact that many Western feminists actually believe they are benefiting the women whose cultures they tend to lack knowledge of. Lastly, because this view is so narrowed down to focusing on ignorance at an individual level, it simply cannot answer our questions pertaining to White ignorance on a much higher level. The next two views, however, will help us answer all of these questions.

\section{The Cognitivist View:}

\section{Definition:}

This view is based on the idea that there are social practices that result in "cognitive errors" which promote faulty reasoning when it comes to racial matters. This type of ignorance is rooted in how knowledge is spread throughout society. The education system, media and our parental figures, being some of the main sources of knowledge for every individual. As Martin (2020) states in her essay on white ignorance, "social practices may promote faulty norms of reasoning that individuals mistakenly take to be valid." Such social practices, or sources of information for many individuals, can lead to misconceptions on culture. For example, throughout their whole life, individual X was told by their parents and the media that the average terrorist has a few key characteristics. In school, individual X also learned about 9/11 and the people involved with one of the largest terrorist attacks in history. Thinking that they have all the information there is to know about this matter, individual $\mathrm{X}$ will automatically link terrorism to Muslims. Individual $\mathrm{X}$ will now go on living life with this misconception (otherwise faulty reasoning) that most Muslims must be dangerous.

\section{How Does This Fit into the Assimilation of Indigenous Canadians?}

The Cognitivist View aids in explaining a very crucial part of the Indigenous Canadians' example: why European Canadians felt the need to save Indigenous women. Around the time of Canada's colonization, it was a very common belief among the Europeans to associate any non-white culture with savagery and impurity. Naturally, the French and the British held that same point of view when it came to the First Nations of Canada. As mentioned, many times before, White Canadians thought of the First Nations cultures, rituals and overall way of life to be savage, unholy and impure. The Europeans, however, viewed women to be the complete opposite: fragile, pure and weak. Another common belief was that the European way of life, or in other words Western culture, was superior in every way. Thus, the White Canadians felt a need to "rescue" Indigenous women from a culture which they thought harmed them and what better way to do that than by introducing them to the "superior" culture.

It was only due to misconceptions that the Europeans initially had that led to this need to save these women from their culture. If society didn't constantly feed White Canadians false knowledge on Indigenous culture, such a need to save these women wouldn't have even existed in the first place. The cognitivist view helps us understand that commonly spread false information at the time led to certain misconceptions and cognitive errors being developed in the minds of European Canadians. Such cognitive errors allowed the White Canadians to view Indigenous culture as 
nothing but harmful towards women. European Canadian's misconception of Indigenous culture being harmful combined with another misconception, European way of life is superior and treats women the best, led to this need for White Canadians to rescue Indigenous women.

\section{Pros and Cons of this View:}

The Cognitivist view is very helpful in answering our main question of why Western Feminists feel the need to save women. Firstly, it is important to note that the example of Native Canadians very much mirrors modern day Western feminism. The idea of "the West is best" is the same as "European way of life is superior." The belief of Indigenous culture being "savage" is a little more intense, however, it still directly correlates to the misconceptions many Western feminists have of Non-western cultures being harmful to women. The modern Western feminist idea of saving women is very similar to the European Canadians' attempt to cleanse First Nations women of their culture.

Now that we have established that this view on White ignorance does not only apply to the Native Canadians example, but Missionary feminism in general as well, we can safely say that the Cognitivist view is able to thoroughly explain this idea of why Westerners feel the need to save women. To recap, social norms and sources of knowledge in Western culture led to common misconceptions that state women in Non-western cultures are oppressed by the traditions in those cultures. It is this misconception that leads Western feminists to believe that in order to help oppressed Non-western women, they must rescue these women from their culture. Because Western Feminists already have this notion that their culture is superior, their immediate plan of action to save women is by stripping them of their previous "oppressive" culture and exposing them to the superior and much more "empowering" Western culture. We also have to take into account that, in most cases, Western feminists truly believe they are helping the women they intend on "saving." It is important to understand that this need to rescue non-Western women often comes from a place of good intent. The Cognitivist model helps clearly illustrate how a person's lack of knowledge on a particular culture, may lead them to believing that the culture is hurting certain women. Wanting to help the women, the most logical plan would be to eliminate the problem, in this case the culture. The individual themselves is not necessarily at fault for believing that they can save women from oppression by rescuing them from cultural practices. It is, however, crucial to understand that although the "need to save women" does not often arise with malicious intent, it is still very much harmful and definitely not the ideal method to solve sexist oppression.

Although this model provides us with a better explanation to one of our main questions, it is still missing the answer to one final question. Where does this dominance sustaining pattern of Western feminism come from? To better understand this question, consider this: there were staff at residential schools who did not like the idea of assimilating these children through such extreme measures. This is a proven fact, with countless stories from the staff themselves to children who recall being helped by staff members during dark times. In this case, we can no longer turn to only the Cognitivist model. This view fails to explain why these staff members were forced to continually convert children into white culture against their own conscience. This example shows how educating oneself is not enough. Individuals may have their own beliefs, because the Cognitivist theory fails to account for those who may further educate themselves on an individual level but must continue to stay white ignorant on a structural level. What I mean by a dominance-sustaining pattern of Western feminism is the forceful push of Western feminist ideology that often occurs in the West. I will touch more on this in my concluding section, however, for now we need to understand that Western feminist ideas are greatly reproduced through institutions.

\section{The Structuralist View:}

\section{Definition:}

The structuralist view of White ignorance accounts for the large institutions in society that have barriers put in place to systematically sustain racial injustice (Martín, 2020). Governments, scientific institutions and many other groups of people who control aspects of our everyday life all fall under this category. To clarify, when I say that an institution is White ignorant, I mean that the people in power in these institutions make decisions from a place of White ignorance. 
These people reflect the institution itself, and therefore, the entire institution can be labelled as white ignorant. On top of that, these institutions have certain practices that are rooted in white ignorance, and although many times these practices are outdated, they are often hard to steer away from. For example, many educational institutions arguably still teach the subject of history, for example, from a very male-white lens. This is a practice that has been going on for a while now and although some curriculums are trying to erase this as much as possible, this process will take a while. It is also important to note that this way of teaching went on for long enough that generations of people still hold knowledge from just that male-white lens. This can be said for almost every other practice in many Western institutions.

The Structuralist view, as a whole, basically states that the greater institutions in our society force certain individuals to stay white ignorant on a structural level. For example, let's say a company has a set of uniforms for all its workers and the uniforms cannot be altered in any way. When coming up with this set of uniforms, the people in power at this company disregarded any cultural issues that people may have with these uniforms. Now, individual $\mathrm{Z}$ is tasked with hiring new employees for the workplace. Candidate A is well qualified for the job and is about to accept when she says she cannot wear the uniform without wearing something under the skirt because she wants to cover her legs. Candidate A explains that her culture does not allow for such attire. With the new uniforms in place, individual $\mathrm{Z}$ has no choice but to take out candidates who refuse to wear the uniform, even if it is due to cultural or religious reasons. Although individual $\mathrm{Z}$ may agree with the woman, they have no choice but to enforce the rules of the company. In this scenario, Individual $\mathrm{Z}$ is being forced to participate in a white ignorant practice. It doesn't matter if they agree or disagree with the corporation, they must comply with its rules. Thus, individual $\mathrm{Z}$ must stay white ignorant on a structural level. The reason this example so clearly illustrates white ignorance is because the people in power completely ignored other cultures when deciding to implement a rule that would affect every employee. Is it not white ignorant for this company to not even take into account other cultures when creating these regulations? Well to put it simply, it definitely is white ignorance, and such examples occur in almost every Western institution, forcing individuals to comply to white ignorant practices. Clearly, people with a certain sense of power should be attentive to these issues.

\section{How Does This Fit into the Assimilation of Indigenous Canadians?}

Going back to the idea I introduced at the end of the last subsection on the Cognitivist view, staff workers in residential schools being forced to comply with rules, we can now see how that fits into the Structuralist view. This theory accurately takes into account the staff workers at the residential schools who may not want to be white ignorant but are forced to due to the schools being mandatory by law. In this example, the government is the main institution that is creating these rules rooted in white ignorance. The ignorance is taking place on a structural level rather than an individual level because one's own opinions do not matter if, in the end, they must comply with whatever the government has set in place.

\section{Pros and Cons of this View:}

Moving forward, I will focus on the Structuralist view because it helps us understand all the questions we have of Western feminism. The view answers our most crucial question in regard to the dominant sustaining pattern of white ignorance that can be seen in Western feminism. Our final question can be answered if we take into account the institutions who show signs of white ignorance. Because the average individual cannot control any of this white ignorance that takes place on a structural level, it forces them to stay white ignorant on a structural level. This can directly be applied to Western feminism because the idea of "saving women," which is a prominent message that many large institutions who practice Western feminism send, is reproduced through structural White ignorance. This view helps to perfectly explain why "saving women" is such a widespread idea in Western feminism and why it continues to grow.

Overall, each view of white ignorance helps us explain a part of Western feminism, however, the structuralist view is most useful for our discussion on why this concept of saving women is constantly used and why the idea of 
all cultural practices being oppressive towards women is reproduced. Now that we understand where these ideas come from and how they are reproduced, we can answer our final questions: how do we stop adhering to Western feminism as an ideal and move towards a feminism that will actually help non-Western women? It is important to realize that at the end of the day, it doesn't matter how much an individual educates themselves. As long as there is still structuralist white ignorance, the challenges that non-Western women face will never be taken care of. We can now apply this idea of White ignorance at a Structural level in order to understand how we can move past this inefficient method of "saving women" and move towards a method that will successfully battle non-Western women's oppression.

\section{Discussion}

\section{Brief Overview of Structural White Ignorance}

We have concluded that the Structuralist view is most relevant to our discussion on why Western feminists feel the need to save women and why there is a pattern of dominating Western feminist beliefs. Now, we can delve deeper into our most important question: why is it that Western feminists' attempts to save women ultimately fail? In order to answer this question, I will be revisiting a few of our main points:

1. The pattern of White ignorance that exists in almost all cases of Western feminism and "saving women."

2. The role of Structural white ignorance.

Both points (1) and (2) are important to understand before we move onto what I call "Structuralist factors" and why I believe that they are the main reason behind why oppressed, non-Western women are only further harmed by Western feminism.

There is simply one main reason behind Western feminists' need to "save" women: White ignorance. In all three examples of Western feminism that we examined, there was a clear pattern of White ignorance. For the Indigenous Canadians, it was the constant misconceptions of First Nations and their culture. For the US and Afghanistan, it was the blatant misinformation of the Taliban and Islam itself. Lastly, for France, it was the lack of knowledge pertaining to hijab and once again misinformation about the religion. Western feminists usually have very little knowledge on the cultures that they attempt to save women from. That, combined with the idea of "the West is best," is why Western feminists have such a strong urge to save women. Whether it is intentional or not, when a Western feminist comes face to face with a non-Western woman, they automatically assume that her culture is the reason for her oppression because they just don't know the truth behind the culture itself. When the Western feminist comes to this conclusion of culture being the only reason behind a woman's oppression, their immediate thought is to completely strip those women of her culture. The thought process behind this is simple: non-Western cultures oppress women and Western culture is a superior environment for women. Therefore, one must "rescue" this woman from oppression by cleansing her of her oppressing culture and introducing her to the superior Western culture. The first point was important to look at because we needed to completely understand this idea of "saving non-Western women" in order to delve into how the Structuralist view of White ignorance plays a role in Western feminism.

The Structuralist view of White ignorance can be perfectly applied to Western feminism. The reason why Western feminist ideas are so widespread and massly reproduced is because they are held at a structural level. The media, government and, to some extent, educational institutions uphold Western feminist beliefs. Someone living in the West who considers themselves to be a feminist is forced to hold a common set of Western feminist beliefs, even if they may not agree with them. During the modern age of social media, issues like this can be witnessed on a daily basis. Anyone who even slightly disagrees with any idea pertaining to Western feminism is called out and even sometimes referred to "not actually being a feminist."

To better understand this idea of dominance of Missionary feminism in the West, it is important to note that this can occur in both a formal feminist setting, as well as a more informal setting (such as the everyday life of a normal person in the West). In terms of a formal setting, someone working for a feminist organization in the West 
will be forced, to some extent, into abiding by the laws of Western feminism as they have no control over how the organization itself operates. On a much more informal level, an individual who sees flaws in Western feminism may try to engage in discussion and uphold their opinions, only to be highly criticized by Western feminists around them. Recall that if one does not comply with the laws of Western feminism in the West, they are often accused of not being a feminist at all. Much of Western feminist ideology is flawed and there are many "Structuralist factors" throughout society that harm women rather than "saving" them. In the end, these harmful Western feminists' beliefs continue to be reproduced on a global scale. The reproduction of these beliefs, along with Structuralist factors, leads to more missionary feminism that hurts non-Western women. But what are these so-called "Structuralist factors" and why do they continue to plague non-Western women? It seems as though Western feminism is looked at as the only true form of feminism and if you derail from core Western feminist beliefs even a little, you are accused of being in the wrong. So why would a feminist in the West ever argue against this type of feminism, it is pushed so much that it must be the only correct view, right? Well, we have discovered that that is simply not the case.

\section{Structuralist Factors and the Role they Play in Women's Oppression}

Before we begin this section, it is important to differentiate Structuralist factors from Structural white ignorance. Structural factors are what I believe to be the main causes of non-Western women's oppression. Structural White Ignorance, however, is a view that helps us understand the ideas of Western feminism, primarily the idea of "saving women." We must understand both concepts in order to effectively battle sexist oppression.

I refer to Structuralist factors as action taken by governments, corporations and other large institutions that force non-Western women into oppressive environments. I believe that usually the main cause of sexist oppression in nonWestern nations is not the culture of the women, but rather these Structuralist factors made by Western entities. To better understand this concept, I will be going back to Alison Jagger's "Saving Aminah" essay. In her essay, Jagger (2005) discusses a few reasons behind why women's oppression cannot only be correlated to non-Western cultural practices: "The poverty and associated abuses suffered by poor women in poor countries, however, cannot be understood exclusively in terms of unjust local traditions." Although she brings up a few key arguments, the points that caught my attention were in relation to colonialism and economic globalization.

Let's start by first looking at Western colonialism and how it has played a role in the lives on non-Western women. Jagger (2005) states that "When discussing issues of seeming injustice in non-Western cultures, however, it is problematic to write as though these cultures are self-contained or autonomous, as though their traditions have not been and do not continue to be shaped by Western interventions." She then brings up a few examples of cultural traditions that Western feminists would clearly portray as oppressive and harmful towards women. It is important to note, however, that these traditions, although tied to the culture, were brought about by Western colonialism. "Many supposed cultural traditions in Asia, Latin America, and Africa have been strongly influenced by encounters with Western colonialism. For instance, Veena Oldenburg argues that the practice of dowry murder in India had imperial origins. Moreover, non-Western cultural practices especially affecting women often gain new life as symbols of resistance to Western dominance" Jagger (2005). I would categorize this as a Structuralist factor because in every case of Western colonialism, women were somehow negatively affected. It is clear that Western colonialism had an evidently negative effect on non-Western women across the globe. Although it can be argued that colonialism is a thing of the past, it is still hypocritical for Western feminists to argue that the West played no role in the oppression of these non-Western women and that the blame should be put solely on the cultures themselves. In reality, however, that is a baseless claim because evidence shows that the West had a variety of harmful impacts on the cultures it chose to colonize, and whether intentional or not, this will continue to be an issue until Westerners own up to their past mistakes.

Although colonialism itself is not as relevant anymore, economic globalization is a very similar, but more modern, issue that I also categorize as a Structuralist error. Jagger (2005) states that "most poor women...traditionally made a living in small-scale and subsistence agriculture...the impact of neoliberal globalization, however, has made 
small-scale and subsistence agriculture increasingly un-viable...as Neoliberalism compels poor countries to open their markets, locally grown agricultural products are unable to compete with the heavily subsidized foods dumped by richer countries." Clearly the agriculture industry, which is controlled by Western entities, plays a significant role in the wellbeing of many women in the global south. Agriculture, however, isn't the only way economic globalization affects women. Jagger (2005) goes on to explain how lack of agricultural jobs has led to women being forced to work in unstable conditions with very low wages. "The decline of small-scale and subsistence agriculture has driven many women off the land and into the shantytowns that encircle most major cities in developing countries...many (women) become street vendors or domestic servants. Those who remain landless in the countryside are often forced to work as seasonal, casual, and temporary laborers at lower wages than their male counterparts. Many women are driven into prostitution, accelerating the AIDS epidemic, which ravages the poorest women in the poorest countries." Like agriculture, Neoliberal globalization has abolished many traditional industries and replaced them with newer ones such as the "garment industry." These newer industries, however, are infamous for their poor working conditions and low income.

The poverty of women is a constant cycle that continues once it has been triggered by an outside source. When a traditional industry is abolished, families go into poverty and women are forced to go find work in either the streets or for Western corporations who have established themselves in these foreign countries. If a woman gets "lucky" and ends up in a garment factory, for example, she will still work under harsh conditions and get paid less than enough to survive. Often, poverty also forces young girls to have to drop out of school and focus on working these low paying jobs instead of getting a proper education. The cycle continues because without education the women are left to continue working the same low paying, harmful, jobs. Lastly, I would also like to add that in conditions of poverty, many times women are forced into marriage at a younger age out of desperation. This is another classic example of how a "cultural" tradition, seen as harmful by Western feminists, was actually brought about by the impact of Westerners themselves. Overall, economic globalization is clearly another Structuralist error because giant Western corporations are making decisions that lead to the harm of non-Western women.

It is evident that Western institutions and corporations play a very large role in the oppression of women in the global south. So why is it that the cultural practices of non-Western women are the only thing to blame when it comes to sexist oppression? Well, we know that the answer to this is white ignorance. Western feminists constantly blame cultures for oppressing women while continually ignoring the Structuralist factors that take place in Western institutions. The reason why so many Western attempts to rescue women from oppression fail is simple: Western feminism continues to contradict itself. It is clearly hypocritical to believe that one can save a non-Western woman from oppression, simply by assimilating her into Western culture. There are a variety of other factors that lead to the oppression of women, poverty being a very critical one. These factors, as we have witnessed, usually stem from Western culture themselves. No matter how many more times Western feminists try to rescue non-Western women, they will continue to fail unless they understand just how much of effect Western entities have on foreign women and their cultures. We know, from the Structuralist theory of white ignorance, that Western feminism dominates the discourse of feminism. We will never be able to help oppressed non-Western women until we (1) move past Western feminism and (2) abolish the Structuralist factors that are found throughout Western society.

\section{Conclusion}

So, where does the misconception of non-Western cultures come from? What are these ideas truly rooted in? How else do we battle the oppression of non-Western women? We now know the answers to those questions. Misconceptions of non-western cultures come from white ignorance that is rooted in large institutions. The dominating pattern of Western feminism forces individuals to stay white ignorant and agree with Western feminists' ideas. Because Western feminists genuinely believe that Western culture is superior and that foreign traditions harm women, they feel the need to "rescue" these women from oppression. Although Western feminists believe that they are actually helping 
these women, many times they are naive and don't understand the real causes of women's oppression. Western feminists have a notion that Western nations play no role in the oppression of women, when in fact they are usually the main cause of their oppression. The Structural factors in Western society force women into oppressive environments and the Structuralist dominance of Western feminism forces feminists to ignore these Structuralist factors. The only way we can battle oppression of non-Western women is by stepping away from Western feminism, especially the idea of foreign cultures being the only cause of oppression for non-Western women. Once we step away from that way of thinking, we will come to understand that Structuralist factors are the real reason behind non-Western women's oppression. We must then abolish these Structuralist factors by forcing Western institutions to stop being white ignorant. Once we combat the structuralist White ignorance in Western institutions and the dominating pattern of Western feminism, then, and only then, will we be able to effectively battle women's oppression across the globe.

\section{Limitations}

I would like to acknowledge a potential limitation to my research and findings. It is important to note that although I believe my theory on eliminating Western feminist beliefs to save women in the Global South is concrete, it is extremely difficult to actually implement and see results. Whenever we are dealing with problems that take place on a structural level, it is important to understand that it takes decades or even centuries before we start seeing change. Above all, it is also important to understand that there is still a lot of discourse around different feminist beliefs and it is currently near impossible to convince every single person, or at least the majority of Western entities, that Western feminism is not the right approach to tackle sexist oppression around the world. There are also thousands of corporations, institutions and people who benefit from the Structuralist factors that need to be abolished in order for this theory to work. Moving forward, I hope that in the future we may move towards a better world where Western entities no longer feel the need to harm foreign nations for their own benefit and where people genuinely consider the needs of cultural others when aiding women in the Global South.

\section{Acknowledgments}

I would like to thank César Cabezas for acting as a mentor throughout my time doing research and helping to plan out my draft for this paper. I would also like to thank the Horizon Academic team for giving me this opportunity and guiding me throughout this process.

\section{References}

Abu-Lughod, L. (2002). Do Muslim Women Really Need Saving? Anthropological Reflections on Cultural

Relativism and Its Others. American Anthropologist, 104(3), 783-790.

https://doi.org/10.1525/aa.2002.104.3.783

Adler, H. (2014, August 24). Indian status: 5 things you need to know. CBC News. https://www.cbc.ca/news/indigenous/indian-status-5-things-you-need-to-know-1.2744870

al-Qaeda. (2003, March 13). Encyclopedia Britannica. https://www.britannica.com/topic/al-Qaeda

Boileau, J. (2021, February 26). Toronto Purchase (Treaty 13). The Canadian Encyclopedia. https://www.thecanadianencyclopedia.ca/en/article/toronto-purchase-treaty-13

Fatawa - A father forcing his daughter to wear the hijab. (n.d.). Dar Al-Ifta al Misriyyah. 
https://www.dar-alifta.org/Foreign/ViewFatwa.aspx?ID=7272

Fatawa - Niqab. (2004). Dar Al-Ifta al Misriyyah. https://www.dar-alifta.org/Foreign/ViewFatwa.aspx?ID=273

French Senate approves burqa ban. (2010, September 15). CNN.

http://edition.cnn.com/2010/WORLD/europe/09/14/france.burqa.ban/index.html

Indian Act. (2006, February 6). The Canadian Encyclopedia.

https://www.thecanadianencyclopedia.ca/en/article/indian-act

Jaggar, A. M. (2005). "Saving Amina": Global Justice for Women and Intercultural Dialogue. Ethics \& International Affairs, 19(3), 55-75. https://doi.org/10.1111/j.1747-7093.2005.tb00554.X

Jason, J. (2020, May 13). France will still ban Islamic face coverings even after making masks mandatory. CBS News. https://www.cbsnews.com/news/france-burqa-ban-islamic-face-coverings-masks-mandatory/

Khader, S. J. (2018). Decolonizing Universalism: A Transnational Feminist Ethic (Studies in Feminist Philosophy). Oxford University Press.

Maizland, L. (2021, August 3). The Taliban in Afghanistan. Council on Foreign Relations. https://www.cfr.org/backgrounder/taliban-afghanistan

Marginalization of Aboriginal women. (2009). Indigenous Foundations. https://indigenousfoundations.arts.ubc.ca/marginalization of aboriginal women/

Martín, A. (2020). What is White Ignorance? The Philosophical Quarterly. Published. https://doi.org/10.1093/pq/pqaa073

McCue, H. A. (2011, May 31). Reserves. The Canadian Encyclopedia. https://www.thecanadianencyclopedia.ca/en/article/aboriginal-reserves

McNab, M. (2006, February 7). Indigenous Women's Issues in Canada. The Canadian Encyclopedia. https://www.thecanadianencyclopedia.ca/en/article/native-womens-issues

Menzies, P. (2020, March 25). Intergenerational Trauma and Residential Schools. The Canadian Encyclopedia. https://www.thecanadianencyclopedia.ca/en/article/intergenerational-trauma-and-residential-schools

Muslim Women Network. (2011, June). Muslim Women Network. https://www.mwnuk.co.uk/Forced Marriage 7 factsheets.php

Plush, H., Peregrine, A., Aldridge, E., \& Peregrine, A. (2016, August 26). Dress code advice for Muslim travellers visiting France. The Telegraph. https://www.telegraph.co.uk/travel/destinations/europe/france/articles/dress-code-advice-for-muslimtravellers-visiting-france/ 
Residential Schools in Canada. (2012, October 10). The Canadian Encyclopedia. https://www.thecanadianencyclopedia.ca/en/article/residential-schools

Spelman, E.V. (2007). Managing Ignorance. Race and Epistemologies of Ignorance, 119-31.

Taliban. (2001, September 28). Encyclopedia Britannica. https://www.britannica.com/topic/Taliban

The Indian Act. (n.d.). Indigenous Foundations. Retrieved 2009, from https://indigenousfoundations.arts.ubc.ca/the indian act/

Veiled women arrested at Paris protest. (2011, April 11). CBC News.

https://www.cbc.ca/news/world/veiled-women-arrested-at-paris-protest-1.1004020 